\title{
Effectiveness of Fiscal Federalism for Poverty Reduction in Nigeria: An Analysis of Federal and State Governments' Expenditures
}

Ebenezer Toyin Megbowon ( $\nabla$ megbowontoyin@gmail.com )

University of Fort Hare https://orcid.org/0000-0003-1319-1304

\section{Samuel Aderoju}

Kwara State University

Gbenga Sanusi

Anchor University Nigeria

\section{Research}

Keywords: Poverty Reduction, Government Expenditure, Fiscal Decentralization, ARDL, Nigeria

Posted Date: November 20th, 2020

DOI: https://doi.org/10.21203/rs.3.rs-108807/v1

License: (c) (i) This work is licensed under a Creative Commons Attribution 4.0 International License.

Read Full License 


\title{
Effectiveness of Fiscal Federalism for Poverty Reduction in Nigeria: An Analysis of Federal and State Governments' Expenditures
}

\author{
Megbowon Ebenezer* \\ University of Fort Hare, South Africa \\ *Corresponding Author \\ Aderoju Samuel \\ Kwara State University, Nigeria \\ Sanusi Gbenga \\ Anchor University, Nigeria
}

\begin{abstract}
One of the sustained political and economic strategies that have been adopted by various countries over three decades to achieve the desired level of development is fiscal federalism. Through this economic development strategy, various levels of government within an economy have been involved in the pursuit of reducing poverty over the decades. The purpose of this study is to examine the relationship between government expenditure on poverty reduction with respect to federal and state government expenditures respectively. The study employed the auto-regressive distributed lag (ARDL) estimation technique to establish long-run relationship, and to examine the magnitude of the effect of federal and state government expenditures in both the short-run and long-run periods using time-series data for the period 1981 to 2018. Results obtained indicate that only state government expenditure has positive effect on poverty reduction in Nigeria. The findings of this study therefore support the need for greater decentralization and increase in fiscal expenditure responsibilities and strengthening revenue capability in favor of state governments, giving that achieving desired poverty reduction could be achieved through increased state government spending.
\end{abstract}

Key words: Poverty Reduction, Government Expenditure, Fiscal Decentralization, ARDL, Nigeria.

JEL Classification: E62, H50, I30 


\section{Introduction}

Theoretically, the Keynes School of thought argues that government's fiscal policy especially her expenditure is a tool for stabilizing the economy, improving economic performance and welfare. This argument is based on the premise that government spending has impact on output, employment, productivity, and income (Keho, 2019). For example, government spending on infrastructure can increase employment through entrepreneurship and awarded projects. This will further increase disposable income, increase aggregate demand, increase private consumption and eventually lead to an improved welfare or reduced poverty. Similarly, governments spending on health and education have the potential to increase efficiency and productivity which often translate to better income, private consumption, leading to a desirably improved welfare. In essence, the role of government in economic growth and development process remain undisputable.

61 One of the sustained political and economic strategies that have been adopted by various governments over three decades to achieve the desired level of development is federalism.

63 Federalism is a system of governance that comprises of multi-ordered government levels 64 (local government, state government and central government) which make-up the general government, with a certain degree of independence of the government units (Dziobek et al., 2011). In this system of governance, power, duties, rights, privileges and decision-making responsibilities regarding generation, allocation and utilization of financial resources, and the provision and distribution of public goods according to Agyeman-Duah et al., (2018) are shared among each of the governance units. The argument for federalism is on the logic that through its governance is brought closer to the people both spatially and institutionally, and government will be more knowledgeable about and responsive to the needs of the people (Crook, 2003).

73 Globally, while there is a wide agreement regarding efficiency and benefits of fiscal federalism, the question in the Nigerian case remain about the effectiveness of expenditure responsibilities of each of the levels of government in the country. This is imperative because as of late governments fiscal in Nigeria has expanded greatly, however, social indicators especially employment, education and health are not improving significantly; poverty rate also has been on the increase. Nigeria is categorized as a lower-middle income country, and it is one of the countries in the sub-Saharan Africa region that has been struggling with serious 
81 (83 million people) are poor because they live below the poverty line of $\$ 381.75$ per year, this 82 make Nigeria to be considered as the poverty capital of the world. Collaborating this is the 83 United Nations (UN) annual Human Development Index (HDI), which categorized Nigeria 84 among countries with low human development index for more than a decade, and currently 85 has low index of 0.534 . This extent of poverty situation in the country is paradoxical in nature 86 in that despite the abundant revenue from oil resource, a lot of people are considered deprived 87 and poor, and this further put a question on the relative impact of government fiscal efforts on 88 the welfare on the citizens. The aim of this study therefore is to investigate the impact of 89 government expenditure on poverty in Nigeria, by taking into consideration the federal system 90 of governance operating in the country. Specifically, the objective of the study is to estimate 91 the long- and short-run impact of federal and state government expenditures responsibilities on 92 poverty reduction. Rest of the paper is organized as follows; second section of the paper 93 present fiscal decentralization structure in Nigeria, relevant empirical literature is presented in 94 section three, section four describes data and analytical techniques used in the study. In the 95 fifth section, empirical results and discussion are presented and the last section presents 96 conclusion and policy recommendations.

\section{Federalism Structure and Government Expenditure Trend in Nigeria}

The fiscal structure of Nigeria is influenced by the system of governance which is according to the Nigerian constitution. Specifically, Nigeria operates a federal system of governance, which is a system of governance that comprises of multi-ordered tiers of governments (local government, state government and central government) which make-up the general government, with a certain degree of independence of the government units (Dziobek et al., 2011). Nigeria's federal system of governance grew from 3 regions during the period 19601966 to 12 states by 1967 , and currently to 36 states and the federal capital territory (FCT). Equally, the number of Local Government areas (LGAs) now 774 had risen from 301 between the years 1976 to 774. In this system of governance, power, duties, rights, privileges and decision-making responsibilities for the supply of public services are shared among each of the

111 decentralized system of government and a significant part of the essential responsibilities of 112 government such as education and health are decentralized to the other levels of government 113 (Dada, 2015). 
Table 1: Responsibilites of Different Government Units/Levels in Nigeria

\begin{tabular}{|l|l|}
\hline $\begin{array}{l}\text { Tier } \begin{array}{l}\text { of } \\
\text { Government }\end{array} \\
\text { Federal } \\
\text { (Central) }\end{array}$ & $\begin{array}{l}\text { Defense; Shipping; Federal trunk roads; Aviation; Railways; Posts, telegraph and } \\
\text { telephones; Police and other security services; Regulation of labor, interstate } \\
\text { commerce, telecommunication; Mines and minerals; Social Security; Insurance; } \\
\text { National statistical system; National Parks; Guidelines for minimum education } \\
\text { standards at all levels; Water resources affecting more than one state; }\end{array}$ \\
\hline $\begin{array}{l}\text { Federal and } \\
\text { State }\end{array}$ & $\begin{array}{l}\text { Antiquities and monuments; Electricity; Industrial, commercial and agricultural } \\
\text { development; Scientific and technological research; Statistics and surveys; University, } \\
\text { technological and post-primary education; Health and social welfare. }\end{array}$ \\
\hline $\begin{array}{l}\text { State and } \\
\text { Local }\end{array}$ & $\begin{array}{l}\text { Primary, adult and vocational education; Health services; Development of agriculture } \\
\text { and non-mineral natural resources. }\end{array}$ \\
\hline Local & $\begin{array}{l}\text { Economic planning and development; Cemeteries; Homes for the destitute and infirm; } \\
\text { Markets; Sewage and refuse disposal; Roads, streets and street lighting, drains, other } \\
\text { public facilities. }\end{array}$ \\
\hline
\end{tabular}

Source: Khemani (2001)

119 The Nigeria government general expenditure have grown tremendiously over the past 20 120 years. The need to meet development demand arising from population dynamics and 121 explosion, spatial expansion and infrasturctural development are among several factrors that 122 have necessitated an increasing government expenditure. The general government expenditure 123 grew from $\$ 254,8851$ billion in the year 1993 to about 13998,31 in 2019 (CBN, 2020). 124 However as seen in Figure 1, the federal government account for about 75 percent of total 125 expenditure in 1993 and 61 percent in 2019. The figure clearly shown that the trend of share of 126 central government spending in the general government expenditure has been higher than the 127 state government share over the years under consideration.

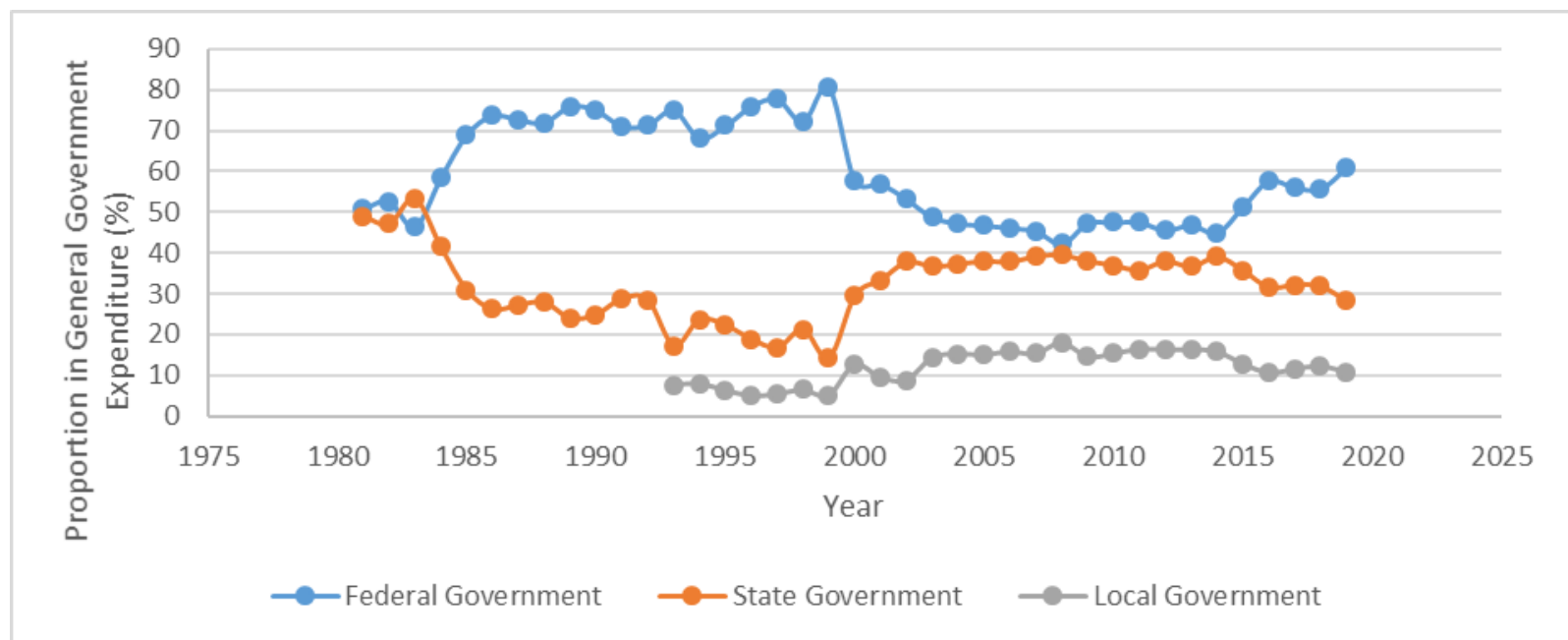

130 Figure 1: Trend in Federal (Central), State and Local Government Expenditure

131 Source: Authors 


\section{Brief Review of Relevant Literature}

Empirically, there is an abundance of literature that have examined the link between or effect of government expenditure on economic development domains which include; income,

141 income inequality, poverty, public service delivery, education outcomes, health outcomes and 142 human capital development among others, this focus on poverty (proxy by expenditure) and 143 HDI in order to avoid excessive heterogeneity. In trying to fill a gap in literature in this area a 144 structured but brief review of literature is conducted by focusing on three relevant areas, in 145 that literature in this area can be categorized into three groups; i) studies focusing on aggregate 146 government expenditure, ii) studies focusing on disaggregated government expenditure and iii) 147 studies that captures fiscal federalism effect.

148 Under the first category, studies have mainly used actual government expenditure or 149 government size which is government expenditure as a percentage of gross domestic product 150 (GDP). Using DOLS, FMOLS and GMM techniques, Liu et al., (2020) demonstrated that 151 increase in government expenditure reduces rural poverty incidence by about 20 percent in 152 Pakistan between 1980 and 2017. Milovich (2018) included government expedniture as a 153 control variable while examining relationship between aid and poverty for a sample of 64 154 developing countries for the period 2000 and 2014. Result from the Two-Stage Least-Squares 155 (2SLS) indicates that government consumption seems to be significantly associated with a 156 decrease in both the income poverty gap and in the multidiemansional poverty index (MPI). A 157 panel DOLS estimation by Kizilkaya et al., (2015) indicates a 0.1 percent increase in human 158 development as a result of one percent increase in public expenditure. The study further 159 argued that the extent of the effect of public expenditure on poverty reduction depend on level 160 of threshold reached and the component of such expenditures. Omar an Inaba (2020) also 161 confirmed that for government expenditure could lower poverty rates following a negative 162 though insignificant computed coefficient value from one-way error component fixed effect 163 model and robust standard errors to address heteroskedasticity estimation techinques. Dhahri 164 and Omri (2020) explored the relationship between FDI and poverty reduction for 50 165 developing countries using Tobit regression estimations, with government expenditure 166 incorporated as a control variable. The coefficient of government consumption was found to 167 have a negative $(\beta=-7.404)$ and statistically significant impacts on the poverty headcount 168 index at a $1 \%$ level. This implies that increasing government expenditure will significantly 
reduce the proportion of individual below poverty line by about 7 percent. The findings of

170 these five studies is however inconsistent with Huay et al., (2019), Kaidi and Mensi (2019).

171 Applying System generalized method of moment (Sys-GMM), Huay et al., (2019) investigated

172 the impact of remittances on human development in 66 developing countries from 1980 to

1732014 by incorporating government expenditure in the model. The significant but negative

174 coefficient of government expenditure means that, when other variables are held constant,

175 increased government expenditure rather than serve as a human development catalyst reduces

176 it. Kaidi and Mensi (2019) revealed that the relationship between government's final

177 consumption expenditure and household final consumption expenditure (a proxy for poverty)

178 is negative at the $1 \%$ level for both democratic and autocratic governments. This imply that a

179 lowered household final consumption expenditure as a result of increase in government

180 expenditure is an increase in poverty level. In this case government expenditure is not a

181 stimulant for improved welfare. Applying Common Correlated Effect Mean Group (CCEMG)

182 estimating technique, Keho (2019) in-line with Huay et al., (2019), Kaidi and Mensi (2019)

183 found that one percent growth in government consumption expenditure leads to a 0.10 percent

184 decline in private consumption in examined ECOWAS countries. This is an indication of

185 crowing out effect in the long-run and short-run periods. The study argued that this situation

186 arises due to the crowding out effect of private consumption, and a negative wealth effect

187 induced by increased government expenditure.

188 In the second group of studies, government expenditure's effectiveness was accessed based

189 expenditure component, such that government expenditure was disaggregated into sectoral

190 component. This is in line with the argument that the effectiveness of government spending on

191 welfare is dependent on sectoral and component of the spending (Anderson et al., 2018). After

192 applying an ARDL estimation technique, Ali et al., (2012) found government development

193 expenditure and education expenditure was found to have significant effect on HDI in Pakistan

194 whereas recurrent expenditure had negative and insignificant impact. The estimated effect of

195 education expenditure is slightly higher than that of development expenditure in the study.

196 Olopade et al., (2019) explored the effect of human capital expenditure proxy by education

197 and health expenditures for 12 OPEC member-countries using Fully Modified Ordinary Least

198 Square between the period 1980 to 2016. The study demonstrated that while public 199 expenditure was shown to have a statically significant trickling down effect of poverty rate by

200 about 1.5 percent, public expenditure on health performed otherwise by not having a 201 statistically significant impact. Haque and Khan (2019) examined the effect sectoral 202 government spending (education, housing and community, social security, public service, 
203 health, defense, and economic services) on HDI in Saudi Arabia using multiple regression 204 estimation technique. Among these seven expenditure components, only three (education, 205 housing and community, social security) were found to have significant positive effect on HDI 206 in the country. Education expenditure with the largest effect is identified as key factor that 207 contributes in the development of the HDI.

208 Celikay and Gumus (2017) analyzed the relationship between social expenditure and poverty 209 in Turkey using panel error correction models on data covering the period 2004-2011 obtained 210 from 26 regions in Turkey. The study found a negative relationship between social 211 expenditure and poverty in the short-run. The study further obtained a negative relationship 212 between education expenditure and poverty, both in the short run and in the long run. 213 Matekenya et al., (2020) public health expenditure has a negative coefficient in a majority of 214 the models, which contradicts a priori expectations. The negative coefficient of public health 215 expenditures may be indicative of inefficiencies in government spending which has been a 216 problem for a number of African economies (Novignon, 2015). In an estimation conducted by 217 Olugunde et al., (2020), government health expenditure was found to have a positive but 218 insignificant relationship $(\beta=0.179 ; p<0.17)$ with HDI among a group of Crude Oil-Producing 219 Countries in Africa. Adegboyo (2020) explored the relationship between the various 220 component of government expenditure and national poverty index in Nigeria, and concluded 221 that government recurrent expenditure on economic service, social and community, and 222 transfer reduces poverty while poverty is escalated as a result of increase in recurrent 223 expenture on administration and transfers' capital expenditure.

224 Ogbonnaya-Udo and Chukwu (2020) investigated the effect of defence, education and health 225 expenditures of government on HDI in a panel of five West African countries for the period 226 2000-2018. The random effect result shows that the effect of expenditure differs, while 227 expenditure on defence is negative and insignificant, the effect is positive for both education 228 and health, it was only however significant for education $(\beta=1.87 \mathrm{E}-11 ; \mathrm{p}<0.05)$. Ordinary 229 least squares regression employed by Linhartová (2020), revealed that though HDI is positive 230 and statistically significantly impacted by Czech Republic government expenditures on public 231 order and safety, housing, health, education, and recreation, culture, and religion, their 232 contribution are however extremely minute. Omari and Muturi (2015) study on Kenya show 233 that government expenditure on agriculture and health has a positive and significant effect on 234 private consumption per capita thereby leading to reduction of poverty level. A one per cent 235 increase in government expenditure on agriculture and health leads to a 0.27 per cent and 1.45 236 per cent respectively increase in private consumption per capita. Whereas the impact of 
237 government expenditure on education was insignificant. Ruch and Geyer (2017) on South 238 Africa concluded that regardless of the estimated models, additional investment in land, 239 transportation infrastructure and specialized vehicles slightly increase poverty. Whereas 240 expenditure on roads, sewerage, street lighting, community assets and electricity consistently 241 contribute to poverty reduction efforts though marginally. Following the very negligible effect 242 on poverty reduction, the authors questions the effectiveness of service delivery as a 243 significant poverty alleviation tool.

244 The third group of studies considered the effectiveness of government expenditure on welfare 245 by examining the effect of fiscal federalism which could be captured by fiscal decentralization 246 or comparing different governance units' expenditure. Fiscal decentralization is 247 conceptualized as the transfer of administrative authority and responsibilities from the national 248 government to other lower government in an economy (Martinez-Vazquez and Lagon-Penas, 249 2017; Udoh et al., 2015). According to Lledó et al., (2018), it captures the share of own fiscal 250 components (revenue, expenditure, tax) of each of the levels of governments (central, 251 state/province/region; and local) as a proportion of general government fiscal components.

252 A bivariate regression analysis conducted by Khanal (2018) in Nepal concluded that fiscal 253 expenditure decentralization cannot promote human poverty reduction which comprises of 254 deprivation in economic provisioning, life expectancy, percentage of people without access 255 safe water. Findings from a normalized equation obtained through Johansen cointegration in 256 the study of Mehmood et al., (2010) concluded that both revenue and expenditure 257 decentralization have a very significant positive effect on human development index in 258 Pakistan. However, the findings show that the magnitude of impact of revenue 259 decentralization is higher than that of expenditure decentralization.

260 Also, Liu et al., (2019) examined the effect of fiscal decentralization on social welfare in 261 China. From the analysis, the effect of fiscal decentralization in the central and western areas 262 are significant and negative, while it is significant and positive through the turning point 263 detection in the eastern area of China. Hadi and Nugroho (2018) finds fiscal decentralization 264 to be significantly but negatively related to poverty which was proxy by the number of poor 265 persons following a fixed effect estimate that was applied over panel data for the period 20092662015 that obtained from 35 districts in Indonesia's central Java Province. The study finding 267 showed that a with one percent increase in fiscal decentralization, the count of poor persons in 268 the Central Java province will reduce by a very small percentage of about 0.003 . The study is 269 however in contradiction with Nursini and Tawakkal, (2019) who used three fiscal 270 decentralization indicators to investigate the effect of fiscal decentralization on poverty 
271 alleviation in same Indonesia. Fixed effect model was employed on data obtained from 33 272 provinces in the country for the period 2010-2016. Main finding of the study is that while 273 regional government revenues and intergovernmental transfers had a statistically significant 274 effect on reducing poverty, regional government expenditures did not. The study argued that 275 the concentration of regional government expenditure on administration proceedings limited 276 the effect of expenditure on poverty reduction.

277 Tebogo et al., (2014) applied VAR and GMM to examine fiscal decentralization-poverty 278 dynamic relationship using information from 8 metropolitan municipalities in South Africa. 279 The study found a negative short-run effect of fiscal decentralization on real household 280 consumption per capita, which consequently imply that fiscal decentralization in South Africa 281 only promotes poverty rather than reducing it. Francisco and Canare (2018) together with 282 other variables investigated the impact of fiscal decentralization on poverty incidence in 283 Philippines. Findings from the two estimation techniques that were applied shows that fiscal 284 decentralization have a positive effect on poverty alleviation. Specifically, the study found that 285 the share of locally-sources revenues is associated with less poverty. Further examination 286 revealed that higher poverty incidence is recorded when fiscal decentralization level increases 287 beyond it optimal point. The result from Sepulveda and Maritinez-Vazquez (2011) is however 288 contrary to Francisco and Canare (2018) in that it found the share of income of local 289 governments which is proxy for fiscal decentralization to be having significantly negative 290 impact on poverty reduction of the 34 developing countries examined from 1970 to 2000.

291 Using GMM estimate over a data period from 1973 to 2013, Shahzad and Yasmin (2016) 292 found fiscal decentralization to be having an increasing effect on poverty in Pakistan. The 293 study shows that one-unit increase in expenditure decentralization lead to 2.7 percent increase 294 in poverty, whereas for revenue decentralization poverty increases by 0.8 percent. The study 295 of Banwo (2012) conducted on Nigeria found different impact of fiscal decentralization 296 indicators on poverty incidence in Nigeria. Specifically, expenditure decentralization had an 297 insignificant capability of increasing poverty.

298 From this brief empirical review, the varied dimensions, scope and focus on poverty together 299 with different conceptualization and computation of government expenditure assessment have 300 contributed to diverse findings on effectiveness of government expenditure. Moreover, it is 301 observed that the effect of extent to which the central government retained fiscal power was 302 not well-thought-out; fiscal decentralization was narrowly focused on aggregating subnational 303 governance tiers such that the effect of each of the subnational government fiscal 304 responsibilities was not considered. Hence, this study attempts to fill this gap by analyzing the 
impact of fiscal federalism on poverty. This is carried out by comparatively investigating and

306 analyzing the effectiveness of both central and state government expenditures on poverty in 307 Nigeria.

\section{Methodology}

\subsection{Model Specification and Variables}

The study adopted a multivariate model specification following Ewetan et al., (2020) and

314 Ugwuanyi et al., (2017) but incorporated different variables in the three models specifying the 315 relationship between the variables of interest. The mathematical expression of the 316 relationships is as follows:

Where $\ln \mathrm{Pov}_{t}$ is poverty indicator and it is represented by household consumption expenditure (Ugwuanyi et al., 2017). This study uses household final consumption expenditure per capita. This is because unlike income which is an indicator for potential in welfare improvement, consumption expenditure is a good proxy for achieved welfare for individuals and households.

324 Besides, the documentation reliability and stability of consumption expenditure over time compare to income especially of poor people validate the use of consumption expenditure in this study. is reliably documented and quite stable when compared with their income (Odhiambo, 2010). Furthermore, the household final consumption expenditure is consistent with the definition of poverty by the World Bank as "the inability to attain a minimal standard of living" gauged relative to their basic consumption needs (World Bank 1990). The proxy has been used in poverty related study by Ugwuanyi et al.,( 2017)

331 Fiscal federalism is represented by both federal and state government expenditures. While $F E$

332 which is the proportion of federal or central government expenditure in total government

333 expenditure and $S E$ which is the proportion of the state government expenditure in total 334 government expenditure. The control variable employed in the analysis is foreign direct 335 investment inflow $(F D I)$. All variables are in natural logarithm form. Foreign direct 336 investment is posited to enhance poverty reduction based on the spillover effect theory. These 337 spillover effect include employment creation and increase in capital investment (Magombeyi 338 and Odhiambo, 2018), development of local skills, increase economic growth with an overall 339 revenue transfer (Magombeyi and Odhiambo, 2018; Ahmad et al., 2019). In short the impact 
of FDI on poverty reduction can be both direct and indirect. From this study a positive

341 coefficient indicates increase in expenditure and consequently a reduction in poverty and vise342 versa.

\subsection{Analytical Techniques}

345 This study utilized the ARDL estimation technique. The ARDL specification of empirical 346 model in eq. (1) is expressed as follows:

$\triangle P_{o v} v_{t}$

$=\alpha_{0}+\sum_{\mathrm{i}=1}^{n} \alpha_{1 \mathrm{i}} \Delta \ln p o v_{\mathrm{t}-\mathrm{i}}+\sum_{\mathrm{i}=1}^{n} \alpha_{2 \mathrm{i}} \Delta \ln F E_{\mathrm{t}-\mathrm{i}}+\sum_{\mathrm{i}=1}^{n} \alpha_{\mathrm{ai}} \Delta \ln S E_{\mathrm{t}-\mathrm{i}}+\sum_{\mathrm{i}=1}^{n} \alpha_{4 \mathrm{i}} \Delta \ln F D I_{\mathrm{t}-1}+\delta_{1} \ln p o v_{\mathrm{t}-1}$

$+\delta_{2} \ln F E_{t-1}+\delta_{a} \ln S E_{t-1}+\delta_{4} \ln F D I_{t-1}+\varepsilon_{i t} \ldots \ldots \ldots m(2)$

Following the ARDL cointegration test which is based on equation (2), the ARDL-based error correction model of the general empirical models is also expressed as follows:

$\triangle P o v_{t}$

$=\alpha_{0}+\sum_{i=1}^{n} \alpha_{1 i} \Delta l n P o v_{t-1}+\sum_{i=1}^{n} a_{2 i} \Delta l n F E_{t-1}+\sum_{i=1}^{n} \alpha_{a i} \Delta l n S E_{t-1}+\sum_{i=1}^{n} \alpha_{4 i} \Delta l n F D I_{t-1}+\gamma_{1 i} E C M_{t-1}$

$+\varepsilon_{i} \ldots \ldots m \ldots m(3)$

Where $\alpha_{0}$ is the constant, $\alpha_{1 i^{-}} \alpha_{4 i}$ are the respective short-run coefficients, ECM is the error correction term, and $\varepsilon_{i}$ is the white noise error term.

ARDL technique was employed because of it advantages over other cointegration techniques. These advantages include; applicability irrespective of the order of integration of series though order of integration should not be beyond order 1, useability with relatively small samples, and possibility of simultaneously estimating long and short-run dynamics (Pesaran et al., 2001; Ewetan et al., 2020; Demirhan, 2020).

\subsection{Data Source}

This study is based annual time series data that cover the period from 1981 to 2018. Data for the study are mainly secondary and they are obtained from the Central Bank of Nigeria and the World Bank Group websites respectively. Total or general government, central (federal) and state government expenditures were obtained from the CBN website, per capita household consumption expenditure and foreign direct investment inflow data were obtained from the World Bank Group website. 


\section{Results and Discussion}

\subsection{Unit Root Stationarity and Cointegration Tests}

Following the criteria that intended variables needed to be integrated in the order of $\mathrm{I}(0)$ or I(1) to so as to be able to apply the ARDL-Bound test cointegration technique, the integrated orders of the variables were examined using the Philips-Perron (PP) and KPSS unit root test measures, and results are presented in Table 2. As shown in the Table 2, there is a sufficient reason to conclude that the level form of the series is not stationary. Consequently, the tests were conducted at first-difference for each of the variables. The results of both PP and KPSS tests indicate that the series are stationary at first difference at 1,5 and 10 percent significance levels respectively. This confirmed that none of the variables (lnPov, $\ln F E$, $\ln S E$, and $\ln F D I)$ are integrated at order above I(1). This further confirm that the ARDL cointegration technique can be applied on the data.

387 Table 2: Order of Integration Test

\begin{tabular}{lcccccc}
\hline Variable & \multicolumn{9}{c}{ PP } & \multicolumn{2}{c}{ KPSS } \\
\hline \multicolumn{2}{c}{ Level } & \multicolumn{2}{c}{ First Difference } & Level & First Difference \\
$\boldsymbol{l n P o v}$ & -1.0001 & 0.7429 & -7.4084 & 0.0000 & 0.6086 & 0.2169 \\
$\boldsymbol{l n} \boldsymbol{F E}$ & -1.1428 & 0.6883 & -7.2233 & 0.0000 & 0.7179 & 0.2499 \\
$\boldsymbol{l n S E}$ & -0.4227 & 0.8948 & -3.5861 & 0.0111 & 0.7049 & 0.1654 \\
$\ln \boldsymbol{F D I}$ & -2.9939 & 0.0447 & -9.7637 & 0.0000 & 0.2557 & 3.8265 \\
\hline
\end{tabular}

Source: Computed by Authors

NB: KPSS significance level value are; $1 \%=0.739000,5 \%=0.463000 .10 \%=0.347000$

As stated earlier, the Bound test cointegration technique was carried out to ascertain the existence of cointegrating relationship among the variables or not in each of the model by comparing the computed F-statistic with the critical values. The AIC was employed to determine the optimal lag structure of the model of ARDL $(1,1,1,0)$.

The result of the Bounds test for the model is presented in Table 3. The result shows that the F-statistic of 8.21 for the model is higher than upper bound I(1) critical value at all levels of significance. This result therefore warrants the rejection of the null hypothesis that there is cointegration relationship existing among the regressands specified in equation 2 , and concluding that there is an existence of long-run relationship among the variables in each of the model.

Table 3: Cointegration Test-ARDL Bound Test

\begin{tabular}{lccccc}
\hline Test Statistic & Value & Significance & $\mathrm{I}(0)$ & $\mathrm{I}(1)$ & Conclusion \\
\hline F-Statistic & 8.21 & $10 \%$ & 2.37 & 3.2 & Co-integration Exist \\
\hline
\end{tabular}




\begin{tabular}{ccccc}
\hline $\mathrm{K}$ & $5 \%$ & 2.79 & 3.67 \\
& $2.5 \%$ & 3.15 & 4.08 \\
& $1 \%$ & 3.65 & 4.66
\end{tabular}

Source: Computed by authors

403

404

405

406

407

408

409

410

\subsection{ARDL long-run and ECM estimation results}

Table 4 presents the results of both long-run and short-run estimations following the establishment of the existence of cointegration relationship among variables in each of the model. As shown in the Table 4, the error correction terms (ECT) for estimated short run period is; -0.818 , this result indicates that each of the model will return to equilibrium with about 82 percent of adjustment taking place in the first year for model after a shock.

The effect of federal government expenditure on poverty reduction varies across period of time, while the effect is insignificant in the short-run, it is however found to be negative but significant $(\beta=-0.23 ; \mathrm{p}<0.01)$ in a longer period of time. The result means that in the long-run, there will be about 0.23 percent increase in poverty as a result of 1 percent increase in federal government expenditure when other variables are held constant. The coefficient of state government expenditure is positive and significant in the long-run $(\beta=0.339 ; p<0.01)$, but positive and insignificant in the short-run. Specifically, in the long-run, one percent increase in the state government expenditure will lead to about 0.34 percent increase in household expenditure and by extension a reduction in poverty is achieved at the same proportion. The positive effect of state government expenditure validates the assertion and argument in favor of fiscal federalism and decentralization that local government will be more knowledgeable about and responsive to the needs of the people (Crook, 2003). Since, the state governments are closer to the masses and more knowledgeable of the need of the people than the federal government, they will as a result carry out expenditures that have positive impact on welfare in both the short and long-term. This finding is also in consistent with Francisco and Canare (2018), though Contrary to Banwo (2012) and Shahzad and Yasmin (2016). Beside the federal government not closer to the people, a further reason why increases in the proportion of federal government expenditure fail in poverty reduction is high level of corruption in the federal or central government and diversion of funds from welfare improving expenditures.

Table 4: Short-run and Long-run Coefficient Estimates, ARDL $(1,1,1,0)$

\begin{tabular}{lcc}
\hline Variables & Coefficients & S.E \\
\hline & Short-run Estimate & \\
$\Delta(\operatorname{InFE})$ & 0.0855 & 0.0637 \\
InSE $)$ & 0.0995 & 0.0647 \\
\hline
\end{tabular}




\begin{tabular}{lcc}
\hline Ect & $-0.8177^{*}$ & 0.1199 \\
LnFE & Long-run Estimate & \\
LnSE & $-0.2322^{*}$ & 0.0623 \\
LnFDI & $0.3385^{*}$ & 0.0580 \\
$\mathrm{C}$ & -0.0101 & 0.0323 \\
$\mathrm{R}^{2}=0.62$ & $0.4970^{*}$ & 0.0829 \\
Durbin Watson=2.06 & \\
Jarque-Bera's Normality Test: $3.6016 ;$ Prob= 0.1652 \\
Breusch-Godfrey Serial Correlation LM Test: F-Statistic=0.2879; \\
Prob. F $(2,28)=0.7521$ \\
Heteroskedasticity-Breusch-Pagan-Godfrey: F-Statistic $=0.6687 ;$ \\
Prob. $\mathrm{F}(6,30)=0.6755$ \\
\hline
\end{tabular}

Source: Computed by authors

432

433

The control variable FDI, is found to be negative and statistically insignificant in the longrun, this is contrary to the a priori expectation of this study. It suggests that FDI inflow in the country does not have the potential of reducing poverty rather it increases it over the short and long period of time. This negative impact of FDI inflow though contrary to a priori expectation of study and the studies of Fowowe and Shuaibu (2014) and Ahmad et al., (2019), it is however consistent with the findings of Huang et al., (2010), Ali et al. (2010) and Anetor et al., (2020) that FDI inflows lead to an increase in poverty levels, which in this study is through reduction in per capita expenditure. A possible explanation for this is the noncomplementary nature of FDI with domestic firm (De Mello, 1999), near absolute crowding out of domestic investment by foreign investment and high level of advanced technology employed by foreign firms such that employment generation that could stimulate consumption expenditure is impeded (Calvo and Hernandez, 2006; Magomgeyi and Odhiambo, 2018).

Table 4 further present results of relevant post-estimation tests that were conducted in order to affirm the soundness and reliability of the estimated models. The statistic report for the JarqueBera test for normality validates the rejection of the null hypotheses that the estimated residual series are not normally distributed. The Serial correlation LM test statistics of 0.287(0.75) suggests that there is no evidence of serial correlation in the model. The Breusch-PaganGodfrey test for heteroskedasticity $0.660(0.67)$, indicates that residual do not suffer from heteroskedasticity. Additionally, Figures 2 shows the CUSUM and CUSUM of squares tests graphs validates the stability of each of the models. 

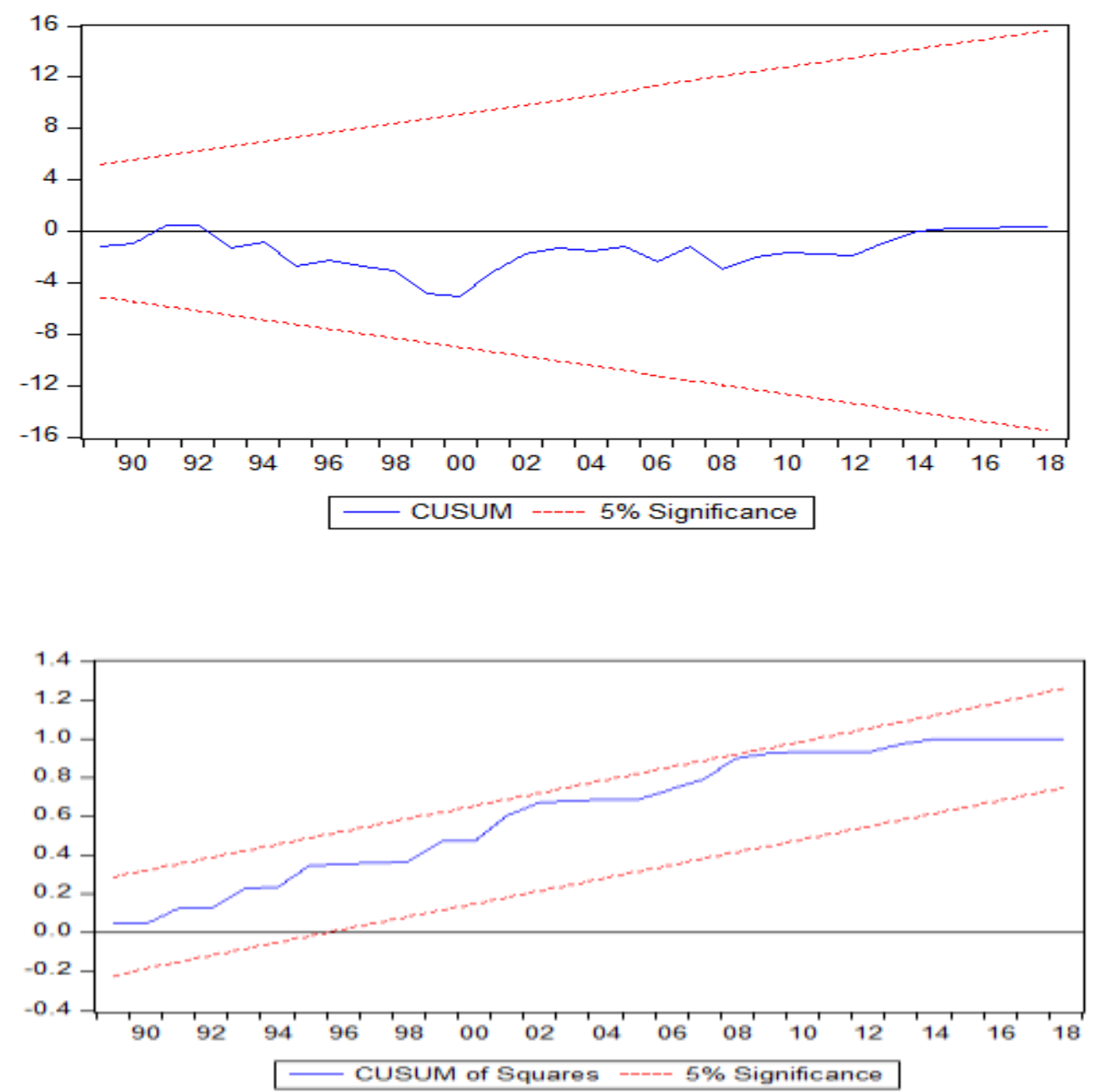

\section{Conclusion and Policy Recommendation}

460 The study analyzed the effect of extent of fiscal decentralization on the poverty reduction in 461 Nigeria using time series data from 1981 to 2018 and the auto-regressive distributed lag 462 (ARDL) bounds testing and estimation technique was employed. Most of the previous studies 463 examined the effect of different forms of fiscal decentralization within an economy on 464 development using various indicators and analytical techniques at mainly subnational level 465 only.

466 However, since fiscal decentralization is the distribution of responsibilities among different 467 levels of governance in the economy, one of the contributions of this study is the government 468 level comparison of the effect of central and state government fiscal responsibilities on 469 poverty reduction in the country. Results from the model consistently indicate that only the 470 state government expenditure has a positive effect on poverty reduction in the long-run. 471 Whereas, the central government expenditure was found to increase poverty level in Nigeria, 472 which is as a result of massive corruption in the central governance. The control variable 
473 (foreign direct investment), was found to be consistently statistically negative irrespective of

474 time, suggesting that FDI inflow in the country does not have the potential of reducing poverty

475 rather it increases it over the short and long period due to its crowding out effect on some

476 macroeconomic components of the economy and employment limiting technologies that is

477 being used by foreign firms. Among others things, the results provide evidence that state

478 governments' expenditures in the general government expenditure has positive effect on

479 poverty reduction in the country.

480 In view of the importance of state government expenditure in enhancing poverty reduction,

481 there is a need to strengthen state government revenue collection ability in order to meet

482 development expenditure needs. In addition, there is a need for higher share of state

483 governments revenue in the monthly revenue allocations in total government revenue so as to

484 increase the level of state government expenditure and by implication reducing poverty level

485 across the country.

486 Abbreviations

487 UN: United Nation; HDI: Human Development Index; FCT: Federal Capital Territor; LGAs:

488 Local Government Areas; GDP: Gross Domestic Product; DOLS: Dynamic Ordinary Least

489 Square; FMOLS: Fully Modified Ordinary Least Square; GMM: Generalized Methods of

490 Moments (GMM); FDI: Foreign Direct Investment; ECOWAS: Ecoonomic Community of

491 West African States; OPEC: Organization of Petroleum Exporting Countries; VAR: Vector

492 autoregression; FE: Federal Government Expenditure; SE: State Government Expenditure;

493 ARDL: autoregressive distributed lag; ECM: error correction model; CBN: Central Bank of

494 Nigeria; PP: Phillips-Perron; KPSS: Kwiatkowski-Phillips-Schmidt-Shin.

495

496

497

498

499

500

501

502

503

504

505

506

507

508

\section{Acknowledgements}

Not applicable.

\section{Authors' contributions}

The authors worked jointly to come up with the paper. Both authors read and approved the fnal manuscript.

\section{Funding}

Not applicable.

\section{Availability of data}

The data for this present study are sourced from the database of the statistical bulletin of Nigeria CBN (https://www.cbn.gov.ng/) and World Development Indicators (https://data.worldbank.org/). Dataset analysed in this study is available from the corresponding author on reasonable request.

\section{Competing interests}

The authors declare that they have no competing interests

\section{Author Details}


${ }^{1}$ Department of Agricultural Economics, University of Fort Hare, South Africa. ${ }^{2}$ Department of Statistics and Mathematical Sciences, Kwara State University, Nigeria. ${ }^{3}$ Department of Economics, Anchor University, Nigeria.

\section{References}

Adegboyo OS (2020) Does government spending reduce poverty in Nigeria? Evidence from Auto-Regressive Distributed Lag Specification. Ekonomi Bisnis 25(1):14-25

Agyemang-Duah W, Gbedoho E, Peprah PA, Arthur FS, Kweku A, Okyere J, Mengba DJ (2018) Reducing poverty through fiscal decentralization in Ghana and beyond: A review. Cogent Economics and Finance 6(1):1-14

Ahmad F, Muhammad UD, Lijuan S, Ilhan O, Abdul R, Shahid A (2019) Impact of FDI inflows on poverty reduction in the ASEAN and SAARC Economies. Sustainability 11(9):2-24

Ali SA, Raza H, Yousuf MU (2012) The role of fiscal policy in human development: the Pakistan's perspective. The Pakistan Development Review 381-394

Ali M, Nishat M, Anwar T (2010) Do foreign inflows benefit Pakistan poor, The Pakistan Development Review 48(4):715-738

Anetor FO, Esho E, Verhoef G (2020) The impact of foreign direct investment, foreign aid and trade on poverty reduction: Evidence from sub-Saharan Africa countries. Cogent Economics and Finance 8(1):1-14

Banwo MA (2012) Fiscal decentralization policy and poverty reduction: lessons from Nigeria, Journal of Emerging Trends in Economic and Management Science 3(4):403-407.

Calvo CC, Hernandez MA (2006) Foreign direct investment and poverty reduction in Latin America. Paper presented at the globalisation and economic policy fifth annual postgraduate conference, Leverhulme Centre for Research on Globalisation and Economic Policy University of Nottingham, 21-22, April 2006.

CelikayF, Gumus E (2017) The effect of social spending on reducing poverty. International Journal of Social Economics 44(5):620-632

Crook RC (2003) Decentralization and good governance. In: Blindenbacker R, Koller A (ed) Federalism in a changing world: learning from each other. Ithaca, McGill-Queens University Press

Dada, Eme A. (2015) Fiscal decentralization and social services in Nigeria, AERC Research Paper 291 African Economic Research Consortium, Nairobi.

De Mello LR (1999) Foreign direct investment-led growth: evidence from time series and panel data. Oxford economic papers 51(1):133-151

Demirhan H (2020) dLagM: An R package for distributed lag models and ARDL bounds testing. PloS One 15(2). doi. org/10.1371/journal.pone.0228812

Dhahri S, Omri A (2020) Are international capital flows really matter for achieving SDGs 1 and 2: ending poverty and hunger?. Review of World Economics 1-37

Dziobek C, Gutierrez Mangas CA, Kufa P (2011) Measuring Fiscal Decentralization-Exploring the IMF's Databases. IMF Working Paper, WP/11/126, International Monetary Fund, Washington DC USA

Ewetan OO, Matthew OA, Babajide AA, Osabohien R, Urhie E (2020) Fiscal federalism and economic development in Nigeria: An auto-regressive distributed lag approach. Cogent Social Sciences 6(1):1-13

Fowowe B, Shuaibu MI (2014) Is foreign direct investment good for the poor? New evidence from African countries. Economic Change and Restructuring 47(4):321-339

Francisco JP, Canare T (2018) An empirical analysis of decentralization and poverty in the Philippines. AIM-RSN PCC Working Paper 18-001 Asian Institute of Management Rizalino S. Navarro Policy Center for Competitiveness 
566

Hadi S, Nugroho S (2018) Is fiscal decentralization able to reduce poverty? empirical cases in Indonesia. International Journal of Civil Engineering and Technology 9:544-552

Haque MI, Khan MR (2019) Role of oil production and government expenditure in improving human development index: Evidence from Saudi Arabia. International Journal of Energy Economics and Policy, 9(2):251-260

Huang CH, Teng KF, Tsai PL (2010) Inward and outward foreign direct investment and poverty: East Asia vs. Latin America. Review of World Economics 146(4):763-779

Huay CS, Winterton J, Bani Y, Matemilola BT (2019) Do remittances promote human development? Empirical evidence from developing countries. International Journal of Social Economics 46(10):1173-1185

Kaidi N, Mensi S (2019)0 Financial development, income inequality, and poverty reduction: democratic versus autocratic countries. Journal of the Knowledge Economy 1-24

Keho Y (2019) Dynamic relationship between government spending and private consumption: evidence from Cote d'Ivoire. International Journal of Economics and Financial Issues 9(1):197-202

Khanal GK (2018) Fiscal decentralization and human poverty in Nepal: a causal analysis Journal of Management and Development Studies 28:1-15

Khemani, Stuti (2001), Fiscal federalism and service delivery in Nigeria: The role of states and local governments, Prepared for the Nigerian PER Steering Committee, 24.

Kizilkaya O, Koçak E, Sofuoğlu E (2015) The role of fiscal policies on human development: An empirical approach. Yönetim ve Ekonomi: Celal Bayar Üniversitesi İktisadi ve İdari Bilimler Fakültesi Dergisi 22(1):257-27

Omar MA, Inaba K (2020) Does financial inclusion reduce poverty and income inequality in developing countries? A panel data analysis. Journal of Economic Structures 9:1-25.1

Linhartová V (2020) The Effect of Government Expenditure on Human Capital in the Czech Republic. Scientific Papers of the University of Pardubice. Series D, Faculty of Economics and Administration 28(2):1-11

Liu L, Donghong D, Jun H (2019) The welfare effects of fiscal decentralization: a simple model and evidence from China. Quality and Quantity 53(1):417-434

Liu Y, Amin A, Rasool SF, Zaman QU (2020) The role of agriculture and foreign remittances in mitigating rural poverty: empirical evidence from Pakistan. Risk Management and Healthcare Policy 13:13-26

Lledó, Victor., Ncuti, Clement, Kabanda, Moses, Hu, C Christina and Xiang, Yuan (2018), The IMF Fiscal Decentralization Dataset: A Primer, International Monetary Fund.

Magombeyi MT Odhiambo NM (2018) Dynamic impact of FDI inflows on poverty reduction: Empirical evidence from South Africa Sustainable Cities and Society 39:519-526

Makreshanska S (2015) Fiscal decentralization and income inequity-cross section analysis of Central and Southeastern European countries, Економски Развој-Economic Development 17(1-2):245-260

Martinez-Vazquez J, Santiago L, Agnese S (2017) The impact of fiscal decentralization: A survey. Journal of Economic Surveys 31(4):1095-1129

Matekenya W, Moyo C, Jeke L. (2020) Financial inclusion and human development: Evidence from Sub-Saharan Africa. Development Southern Africa 1-18

Mehmood R, Sara S, Khalid M (2010) Impact of fiscal decentralisation on human development: a case study of Pakistan, The Pakistan Development Review 513-530

Milovich, J. Y. (2018). Does aid reduce poverty?. OPHI Working Paper No 122 Oxford Poverty \& Human Development Initiative (OPHI) Oxford Department of International Development Queen Elizabeth House (QEH), University of Oxford 3 Mansfield Road, Oxford OX1 3TB, UK

National Bureau of Statistics (2019) 
Nursini N, Tawakkal (2019) Poverty alleviation in the context of fiscal decentralization in Indonesia. Economics and Sociology 12(1):270-285

Odhiambo NM (2010) Is financial development a spur to poverty reduction? Kenya's experience. Journal of Economic Studies. Journal of Economic Studies 37(3):343-353

Ogbonnaya-Udo N, Chukwu KO (2020) Effect of government expenditure on economic development: a study of selected West African countries. Asian Journal of Advanced Research and Reports 24-36

Ologunde IA, Kapingura FM, Sibanda K (2020) Sustainable development and crude oil revenue: a case of selected crude oil-producing African countries. International Journal of Environmental Research and Public Health, 17(18): 6799; doi:10.3390/ijerph17186799

Olopade BC, Okodua H, Oladosun M, Asaleye AJ (2019) Human capital and poverty reduction in OPEC member-countries. Heliyon 5(8):1-7

Omari LV, Muturi W (2016) The effect of government sectoral expenditure on poverty level in Kenya. Journal of Economics and Sustainable Development 7(8):219-242

Pesaran MH, Shin Y, Smith RJ (2001) Bounds testing approaches to the analysis of level of relationships. Journal of Applied Econometrics 16(3):289-326

Ruch W, Geyer Jr HS (2017) Public capital investment, economic growth and poverty reduction in South African Municipalities. Regional Science Policy and Practice 9(4):269-284.

Sepúlveda C, Martínez-Vázquez J (2011) The consequences of fiscal decentralization on poverty and income inequality. Environment and Planning C: Government and Policy 29(2):321-343

Shahzad S, Yasmin B (2016) Does fiscal decentralisation matter for poverty and income inequality in Pakistan? The Pakistan Development Review 781-802

Tebogo MJ Monkam N, Aye G (2014) Fiscal decentralization and poverty in South Africa: evidence from panel data analysis Investment Management and Financial Innovations Volume 11(2):69-76

Udoh E, Udoma A, Elias AU (2015) Fiscal decentralization, economic growth and human resource development in Nigeria: Autoregressive Distributed Lag (ARDL) approach CBN Journal of Applied Statistics 6(1):9-93

Ugwuanyi U, Ezeaku H, Imo I (2017) The impact of officia; aid on poverty reduction: empirical evidence from Nigeria (1981-2014) using the ARDL and bound Test Approach. Europen Journal of Sustainable Development 6(2):111-120.

World Bank (1990) World Development Report 1990, Poverty, Oxford University Press, New York, NY. 
Figures

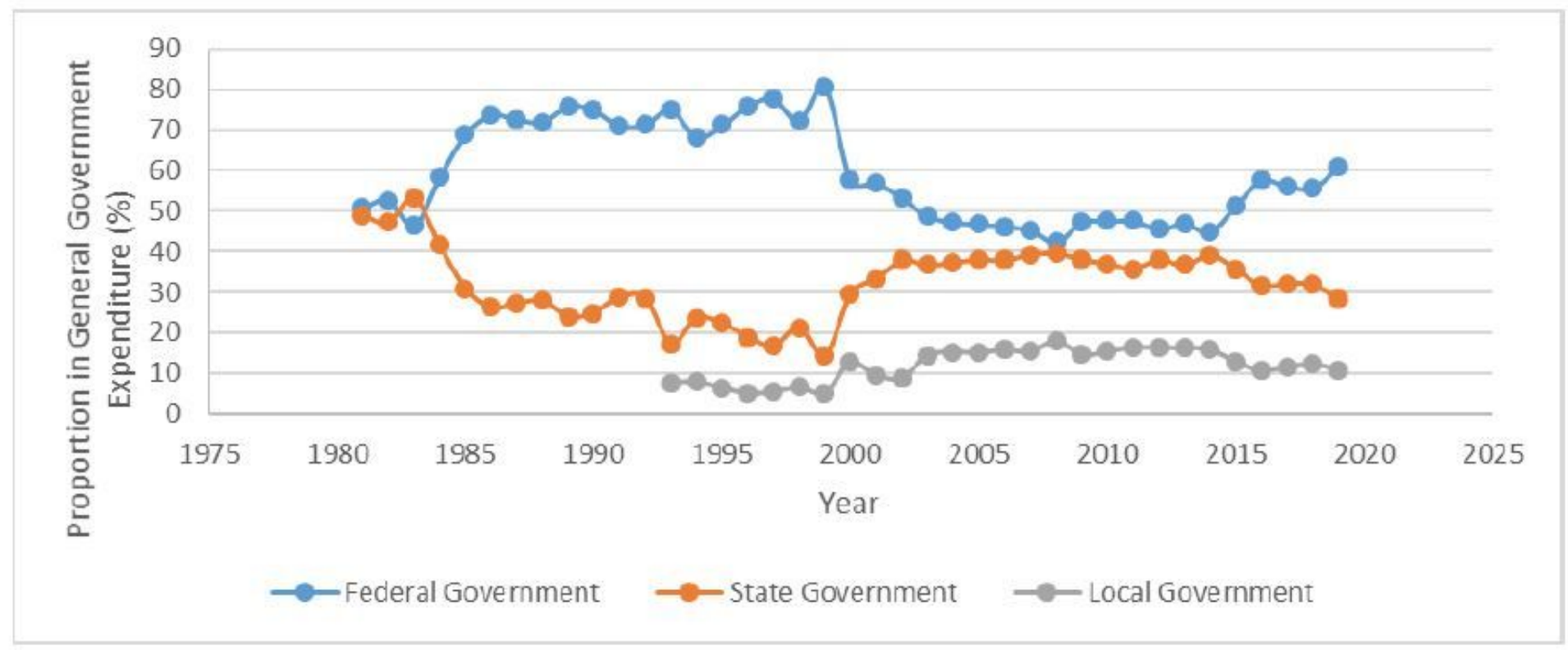

\section{Figure 1}

Trend in Federal (Central), State and Local Government Expenditure Source: Authors 